\title{
The Dynamics and Environmental Influence on Interactions Between Cassava Brown Streak Disease and the Whitefly, Bemisia tabaci
}

\author{
S. C. Jeremiah, I. L. Ndyetabula, G. S. Mkamilo, S. Haji, M. M. Muhanna, C. Chuwa, S. Kasele, \\ H. Bouwmeester, J. N. Ijumba, and J. P. Legg
}

\begin{abstract}
First, sixth, and seventh authors: Ministry of Agriculture, Food Security and Cooperatives-Ukiriguru Research, P.O. Box 1433, Mwanza, Tanzania; second author: Ministry of Agriculture, Food Security and Cooperatives-Maruku Research, P.O. Box 127, Bukoba, Tanzania; third author: Ministry of Agriculture, Food Security and Cooperatives-Naliendele Research, P.O. Box 509, Mtwara, Tanzania; fourth author: Ministry of Agriculture, Food Security and Cooperatives-Kizimbani Research, P.O. Box 159, Zanzibar, Tanzania; fifth author: Ministry of Agriculture, Food Security and Cooperatives-Kibaha Research, P.O. Box 30031, Kibaha, Tanzania; eighth author: Geospace, Roseboomlaan 38, 6717 ZB Ede, Netherlands; ninth author: Nelson Mandela African Institute of Science and Technology, P.O. Box 447, Arusha, Tanzania; and tenth author: International Institute of Tropical Agriculture, P.O. Box 34441, Dar es Salaam, Tanzania.
\end{abstract}

Accepted for publication 20 December 2014.

\section{ABSTRACT}

Jeremiah, S. C., Ndyetabula, I. L., Mkamilo, G. S., Haji, S., Muhanna, M. M., Chuwa, C., Kasele, S., Bouwmeester, H., Ijumba, J. N., and Legg, J. P. 2015. The dynamics and environmental influence on interactions between cassava brown streak disease and the whitefly, Bemisia tabaci. Phytopathology 105:646-655.

Cassava brown streak disease (CBSD) is currently the most significant virus disease phenomenon affecting African agriculture. In this study, we report results from the most extensive set of field data so far presented for CBSD in Africa. From assessments of 515 farmers' plantings of cassava, incidence in the Coastal Zone of Tanzania ( $46.5 \%$ of plants; $87 \%$ of fields affected) was higher than in the Lake Zone (22\%; 34\%), but incidences for both zones were greater than previous published records. The whitefly vector, Bemisia tabaci, was more abundant in the Lake Zone than the Coastal Zone, the reverse of the situation reported previously, and increased B. tabaci abundance is driving CBSD spread in the Lake Zone. The altitudinal "ceiling" previously thought to restrict the occurrence of CBSD to regions $<1,000$ masl has been broken as a consequence of the greatly increased abundance of B. tabaci in mid-altitude areas. Among environmental variables analyzed, minimum temperature was the strongest determinant of CBSD incidence. B. tabaci in the Coastal and Lake Zones responded differently to environmental variables examined, highlighting the biological differences between $B$. tabaci genotypes occurring in these regions and the superior adaptation of $B$. tabaci in the Great Lakes region both to cassava and low temperature conditions. Regression analyses using multi-country data sets could be used to determine the potential environmental limits of CBSD. Approaches such as this offer potential for use in the development of predictive models for CBSD, which could strengthen country- and continent-level CBSD pandemic mitigation strategies.
Cassava brown streak disease (CBSD) has been recognized as a major constraint to cassava production in some parts of East and Central Africa since the early years of the last century (Nichols 1950; Storey 1936; Thresh et al. 1994). CBSD is caused by viruses in the family Potyviridae; genus Ipomovirus (Monger et al. 2001). More recently, whole genome sequencing has demonstrated the occurrence of two distinct species causing CBSD (Mbanzibwa et al. 2009; Winter et al. 2010). These have been designated Cassava brown streak virus (CBSV) and Ugandan cassava brown streak virus (UCBSV) (Mbanzibwa et al. 2010), collectively referred to here as cassava brown streak viruses (CBSVs). CBSD symptoms are very variable and may be expressed in leaves, stems, fruits, and tuberous roots (Bock 1994; Nichols 1950). Although symptoms may differ between isolates of the two virus species, there are large overlaps which mean that the infections caused by each of the two virus species cannot be diagnosed on the basis of visual symptom assessment (Mohammed et al. 2012). The combination of symptoms expressed varies between varieties although there is an association between the range and severity of above-ground symptoms and the severity of symptoms in tuberous roots (Hillocks et al. 1996). Leaf symptoms are most pronounced in mature leaves and comprise a blotchy yellow chlorosis that in some varieties is clearly associated with minor veins (Hillocks and Jennings 2003).

Corresponding author: J. P. Legg; E-mail address: j.legg@cgiar.org
The earliest information on the distribution of CBSD was provided by Nichols (1950), who noted that the disease was an important constraint to cassava production in coastal areas of Kenya and Tanzania (including Zanzibar), as well as the lakeshore areas of Malawi. He also anticipated the presence of CBSD in Mozambique, although this was not proven until much later (Hillocks et al. 2002). Localized outbreaks were also recorded in the 1940s in parts of Uganda, although a vigorous eradication program was thought to have eliminated the disease (Jameson 1964). CBSD was only rarely observed and was of no economic significance in Uganda through the second half of the 20th century (Alicai et al. 2007).

During the early years of CBSD research in Tanzania it was noted that conditions at altitudes greater than approximately $1,000 \mathrm{~m}$ above sea level (masl) were unfavorable for the survival of the disease (Nichols 1950). Cold temperatures were thought to enhance symptom severity and to lead to the death of infected plants through die-back from the shoot tip. Additionally, the lack of any secondary infection at altitudes greater than approximately 1,000 masl was considered to be the result of the absence of vector activity. However, no definitive proof had been presented by that stage on the identification of the vector, although it was suspected from the outset that Bemisia tabaci (Genn.) (Hemiptera: Aleyrodidae) whiteflies were the most likely vector. More recently, this has been confirmed experimentally (Jeremiah 2014; Maruthi et al. 2005). The early suggestion that CBSD incidence was greatest in coastal lowlands and declined with increasing altitude was supported by further studies in both Tanzania (Hillocks et al. 1999) and Mozambique (Hillocks et al. 2002). 
New outbreaks of CBSD were reported from central southern Uganda in 2004 (Alicai et al. 2007), and subsequently from the Lake (Victoria) Zone of Tanzania (Anonymous 2008) and western Kenya (HM, Obiero, KARI-Kakamega, Kenya, unpublished data). The presence and obvious spread of CBSD at altitudes hitherto considered to be unfavorable for the disease has raised questions about the factors responsible for this change in behavior. Reports of the occurrence of CBSVs from Burundi (Bigirimana et al. 2011) and eastern Democratic Republic of Congo (DRC) (Mulimbi et al. 2012) have further emphasized the growing importance of CBSD in the Great Lakes region, most of which lies above 1,000 masl. Moreover, this regional pattern of spread has resulted in an epidemiological characterization of CBSD in this region as a pandemic, driven by superabundant populations of B. tabaci (Legg et al. 2011, 2014b). As CBSD continues to spread to previously unaffected parts of East and Central Africa, it is having a significant negative impact on cassava productivity. Losses are having devastating impacts on the livelihoods of the worst-affected communities (Anonymous 2008) and overall losses attributable to CBSD regionally have been conservatively estimated at $7.5 \%$ of total production in the worst-affected countries (Malawi, Mozambique, Tanzania, and Uganda), equivalent to $>\$ 70$ million (Manyong et al. 2012). In view of the growing economic and social consequences of this developing pandemic, it is essential to improve understanding of the dynamics of the disease. It is particularly critical to determine how environmental factors interact with CBSD, and why this disease has only recently begun to spread at altitudes of $>1,000$ masl, more than half a century after it had first been reported as an important disease of cassava throughout much of coastal East Africa. Improvements in knowledge in these fields of research will help in forecasting future patterns of CBSD spread, determining the likely impacts of climate change on the pathosystem, and developing improved disease management strategies. In the research presented here, Tanzania was used as a case study to investigate the dynamics of CBSD. This country was determined to be the most appropriate for this purpose since previous published work is available that provides a baseline reference for comparison (Hillocks et al. 1999; Legg and Raya 1998). The current study was part of a larger initiative to monitor and manage cassava virus diseases in the Great Lakes region of East and Central Africa.

\section{MATERIALS AND METHODS}

Sampling locations. Assessments of CBSD status were made in farmers' cassava fields in the two main cassava-producing zones of Tanzania: the lowland Coastal Zone, including the islands of Zanzibar, and the mid-altitude Lake Zone (Victoria and Tanganyika) (Fig. 1). Surveys in both zones were done during the dry season between July and September 2009. The study covered 36 districts: 13 in the Coastal Zone and 23 in the Lake Zone. In view of its size, Zanzibar was considered as a district. Assessments were taken from young ( 3 to 6 months old) cassava fields, selected at approximately $10 \mathrm{~km}$ intervals along motorable roads. Fifteen farmers' fields were usually sampled in each district. Fewer fields were considered in a few districts in the Lake Zone in view of the scarcity of cassava crops in these areas. Each of the 515 farmers' fields was assessed as described below.

Field data collection. (i) GPS data. Longitude, latitude, and altitude, recorded using a Garmin Etrex hand-held GPS unit.

(ii) Whitefly abundance. Adult B. tabaci whiteflies were counted on the top five apical leaves of the tallest shoot of each of 30 plants sampled at regular intervals along the two diagonals running across the field.

(iii) CBSD. Foliar symptoms of CBSD were assessed for each of the 30 sampled plants using a severity scale of 1 to 5 , where 1 represents no symptoms and 5 represents the most severe symptoms that include stem streaking and shoot tip die-back (Hillocks et al. 1996). The field incidence of CBSD was calculated as the percentage of plants out of 30 expressing CBSD foliar symptoms (scores 2 to 5). Average CBSD severity was calculated as the mean value of severity scores for all CBSD-symptomatic plants among the 30 sampled in each field. Asymptomatic plants (score 1) were therefore not included in mean severity calculations.

Historical data comparisons. Whitefly abundance and CBSD incidence data were compared with historical data obtained from a survey in 1993/94, which was conducted by Legg and Raya (1998) and which used similar methods to those described under the field data collection section above.

Mapping. ArcGIS software (Environmental Systems Research Institute, Inc., Redlands, USA) was used to map the locations of sampled sites in target districts (Fig. 1) and subsequently to link these to minimum temperature in the coolest month of July, mean annual rainfall, and length of growing season obtained from a high-resolution interpolated surface (Environmental Research Group Oxford 2005; Hijmans et al. 2005). Values for districts were calculated by taking the arithmetic mean of the sampled fields located within each district.

Analysis. Regression analyses were run, using SigmaPlot 11.0 (Systat, Inc., Chicago, IL), to compare the relationships between CBSD and altitude for the coastal part of the 2009 survey data with published data of previous studies conducted in Tanzania (Hillocks et al. 1999; Legg and Raya 1998). Regression was additionally used to examine the relationship between whitefly abundance and both altitude and CBSD incidence, as well as the possible link between minimum temperature, rainfall or growing period and incidence or severity of CBSD. For this second set of regression analyses, only parts of the Lake Zone identified as being affected by CBSD during the 2009 survey were included.

\section{RESULTS}

CBSD distribution and incidence. Prior to 2004, CBSD was only reported as a significant problem in coastal areas of East Africa and the lakeshore areas of Malawi (Hillocks and Jennings 2003; Nichols 1950). The 1993/94 survey of CBSD in Tanzania (Legg and Raya 1998) highlighted the marked contrast between coastal areas (average incidence $=14.8 \%$ ) and those in the Lake Zone of the northwest (average incidence $=0.2 \%$ ) (Fig. 2). In the 2009 survey reported here, average incidence for the 515 fields surveyed in Tanzania was $31.7 \%$, comprising $46.5 \%$ in the Coastal Zone (194 fields) and $22.6 \%$ in the Lake Zone (321 fields) (Fig. 2). Within these regions, incidence was highest in the northern and central parts of the Coastal Zone (Fig. 2; Table 1), while in the Lake Zone incidences were greatest in districts to the south and east of Lake Victoria (Fig. 2; Table 1). CBSD was less evenly distributed in the Lake Zone than in the Coastal Zone. In the Lake Zone, $33.6 \%$ of fields were affected by CBSD (in 12 of 23 districts) compared with $87.1 \%$ of fields in the Coastal Zone (in all 13 districts). It was significant, however, that the three districts with highest overall incidences of CBSD were in the Lake Zone (Ukerewe, 93.6\%; Ilemela, 93.3\%; and Musoma Rural, 88.0\%). If only districts with at least one field affected by CBSD are considered when calculating mean CBSD incidence in the Lake Zone, the figure rises to $42.6 \%$, which is closely comparable with the mean incidence for affected districts in the Coastal Zone (46.5\%). The on-going epidemic of CBSD in the Lake Zone continues to spread, but has a restricted distribution. In 2009, the area to the south and west of the Zone was considered to be not yet affected (including the districts of Bukoba Rural, Karagwe, Ngara, Bukombe, Kibondo, Kasulu, Kigoma Rural, Kahama, Urambo, and Nzega). Consequently, for the subsequent analysis of relationships between CBSD, whiteflies and environmental variables, it was decided to consider only the affected part of the Lake Zone, which is hereafter referred to as the "Lake (CBSD) Zone." Additionally, the complete set of surveyed districts in the Lake Zone is referred to as the "Lake Zone," and the western unaffected portion as the "Lake (no CBSD) Zone."

CBSD severity. CBSV severity, based on symptomatic plants having a score of 2 or greater, was higher in the Coastal Zone (2.8) 


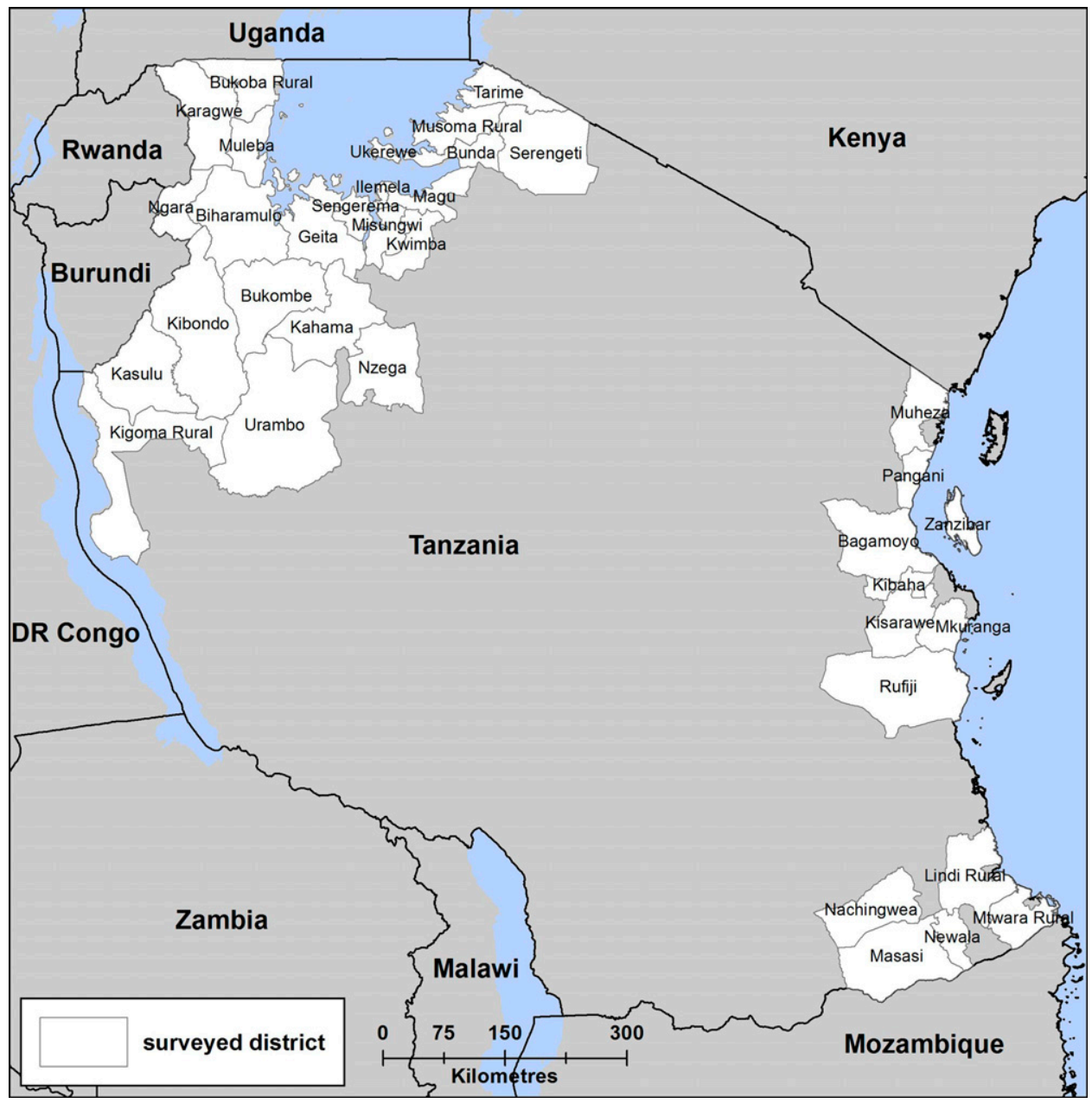

Fig. 1. Surveyed districts in Tanzania, 2009.

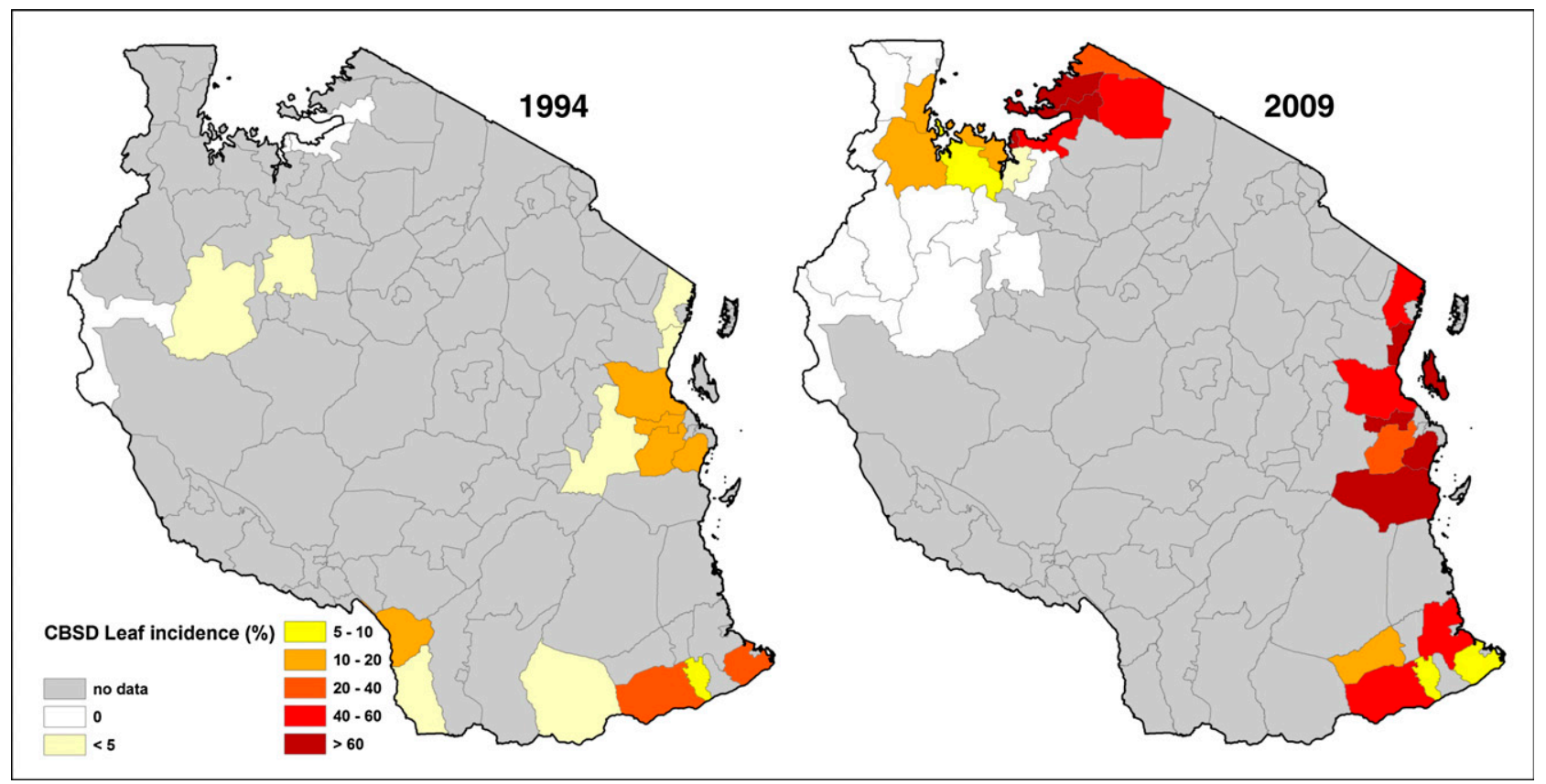

Fig. 2. Distribution and incidence of Cassava brown streak disease in Tanzania (1994 and 2009). 1994 data - Legg and Raya 1998 (http://www.tandfonline.com). 
than in the Lake Zone (2.3). Only one district in the Lake Zone (Musoma Rural, 2.8) had a mean severity value greater than the overall mean for the Coastal Zone; all others ranged from 2.0 to 2.5 (Table 1). CBSD severity in the Coastal Zone was highest in Masasi (3.2) in southern Tanzania.

Abundance of $\boldsymbol{B}$. tabaci whiteflies. In 2009, B. tabaci whitefly adults were much more abundant in the Lake Zone (10.0) (Table 1) than they were in the Coastal Zone (1.90) (Table 1). This pattern was the inverse of that recorded during the earlier 1993/4 survey (Legg and Raya 1998) (Fig. 3), when B. tabaci was more abundant in lowland coastal districts. Overall, whiteflies were more abundant in 2009 (7.0) than they had been in 1994 (4.4). In the Coastal Zone in 2009, abundances were greatest in the central districts (Kibaha, Kisarawe, Mkuranga, and Bagamoyo) and least in the southern districts (Newala, Masasi and Nachingwea). There was only moderate variation in whitefly abundance between districts, and mean values ranged from 0.05 to 5.9. In the Lake Zone, B. tabaci populations were greatest in the westerly districts of Muleba, Bukombe, Karagwe, and Ngara, as well as Ukerewe Island, and least in areas to the south of Lake Victoria (Magu, Kwimba, Misungwi, Kahama, and Nzega). There was more variation in abundance than recorded in the Coastal Zone, as mean abundances varied from 0 to 50 (Table 1).

Relationship between CBSD incidence and altitude. The average altitude in the Coastal Zone was 198 masl, in contrast to the Lake Zone where it was 1,254 masl. The relationship of CBSD

TABLE 1. Cassava brown streak disease (CBSD) foliar incidence, severity and whitefly abundance in the Coastal and Lake Zones of Tanzania, 2009

\begin{tabular}{|c|c|c|c|c|c|}
\hline Zone & District & $\begin{array}{l}\text { Number } \\
\text { of fields }\end{array}$ & $\begin{array}{l}\text { CBSD foliar } \\
\text { incidence }(\%)\end{array}$ & $\begin{array}{c}\text { CBSD } \\
\text { severity }\end{array}$ & $\begin{array}{c}\text { Whitefly } \\
\text { abundance }^{\text {ab }}\end{array}$ \\
\hline \multicolumn{6}{|l|}{ Coastal } \\
\hline \multirow[t]{14}{*}{ Zone } & Muheza & 15 & 47.3 & 2.7 & 1.0 \\
\hline & Pangani & 15 & 64.2 & 2.8 & 2.0 \\
\hline & Kibaha & 15 & 72.0 & 2.8 & 5.9 \\
\hline & Bagamoyo & 15 & 52.4 & 2.7 & 3.0 \\
\hline & Kisarawe & 15 & 26.9 & 2.4 & 3.5 \\
\hline & Mkuranga & 15 & 80.9 & 2.7 & 3.3 \\
\hline & Lindi Rural & 15 & 59.1 & 2.9 & 1.6 \\
\hline & Nachingwea & 14 & 12.9 & 2.8 & 0.7 \\
\hline & Masasi & 15 & 44.9 & 3.2 & 0.3 \\
\hline & Newala & 15 & 9.8 & 2.6 & 0.1 \\
\hline & Mtwara Rural & 15 & 8.4 & 2.5 & 1.5 \\
\hline & Rufiji & 14 & 62.9 & 2.5 & 0.9 \\
\hline & Zanzibar & 16 & 62.0 & 3.0 & 0.8 \\
\hline & Mean/(total) & (194) & 46.5 & 2.8 & 1.9 \\
\hline \multicolumn{6}{|l|}{ Lake } \\
\hline \multirow[t]{24}{*}{ Zone } & Kigoma Rural & 15 & 0 & - & 3.8 \\
\hline & Kasulu & 15 & 0 & - & 7.9 \\
\hline & Kibondo & 14 & 0 & - & 7.3 \\
\hline & Kahama & 15 & 0 & - & 0.2 \\
\hline & Bukombe & 15 & 0 & - & 31.8 \\
\hline & Nzega & 15 & 0 & - & 0.2 \\
\hline & Urambo & 15 & 0 & - & 4.3 \\
\hline & Sengerema & 15 & 18.7 & 2.3 & 7.0 \\
\hline & Geita & 15 & 6.4 & 2.2 & 3.1 \\
\hline & Magu & 15 & 42.7 & 2.2 & 0.5 \\
\hline & Ukerewe & 15 & 93.6 & 2.4 & 19.8 \\
\hline & Misungwi & 15 & 0.4 & 2.0 & 0.4 \\
\hline & Kwimba & 10 & 0 & - & 0 \\
\hline & Ilemela & 5 & 93.3 & 2.0 & 11.8 \\
\hline & Karagwe & 7 & 0 & - & 20.8 \\
\hline & Bukoba Rural & 15 & 0 & - & 3.7 \\
\hline & Ngara & 15 & 0 & - & 18.3 \\
\hline & Muleba & 15 & 12.2 & 2.3 & 50.0 \\
\hline & Biharamulo & 15 & 18.9 & 2.4 & 8.5 \\
\hline & Bunda & 15 & 80.2 & 2.5 & 2.6 \\
\hline & Musoma Rural & 15 & 88.0 & 2.8 & 9.7 \\
\hline & Serengeti & 15 & 54.9 & 2.1 & 11.4 \\
\hline & Tarime & 15 & 35.3 & 2.2 & 11.0 \\
\hline & Mean/(total) & $(321)$ & 22.6 & 2.3 & 10.0 \\
\hline
\end{tabular}

a Whitefly abundance values are the mean number of Bemisia tabaci adults on the top five leaves of a single sampled shoot per plant. incidence to altitude shows a bimodal distribution (Fig. 4). In the Coastal Zone, it is apparent from the data for all 194 sampled sites that CBSD incidence declines with increasing altitude. For the Lake (CBSD) Zone the pattern is less obvious. Regression analyses testing the association between altitude and CBSD incidence showed a negative relationship for 1994 (Legg and Raya 1998), for 1996 (Hillocks et al. 1998), and for the current 2009 data set for the Coastal Zone (Fig. 5). The gradient of the regression has increased over time, reflecting the higher CBSD incidence of low altitude locations in 2009. Although the relationship between CBSD and altitude was strongly inverse for the Coastal Zone $(P<$ $0.001)$, it was less strongly significant for the Coastal and Lake (CBSD) Zones combined $(P=0.003)$, and marginally nonsignificant for the Lake (CBSD) Zone $(P=0.085)$. However, if only fields in Lake (CBSD) Zone districts considered to be widely affected by CBSD (defined as those districts with $>50 \%$ of fields with at least some CBSD infection [eight districts]) were included in the analysis, the inverse linear relationship is strongly significant $(P=0.0054)$. The data therefore describe a "two-step" relationship between CBSD and altitude in Tanzania, in which CBSD incidence declines in the eastern coastal zone as altitude increases from 0 to 800 masl, and similarly declines with increasing altitude from 1,100 to 1,600 masl in the Lake Zone.

Relationship between $B$. tabaci whiteflies and altitude. As described previously, the overall abundance of $B$. tabaci was much greater in the Lake Zone than in the Coastal Zone. A positive linear relationship $(P<0.001)$ between whitefly abundance and altitude for all surveyed sites was demonstrated (Table 2). Figure 6 highlights the contrast in $B$. tabaci population sizes between the two Zones, but also suggests a negative relationship between whitefly abundance and altitude within the Coastal Zone, confirmed by regression results presented in Table 2 . By contrast, there was no significant relationship between whitefly abundance and altitude in the Lake (CBSD) Zone (Table 2). This indicates that the positive relationship between altitude and whitefly abundance for all zones was a consequence of the generally higher abundance of whiteflies in the Lake (CBSD) Zone than in the Coastal Zone.

Relationship between B. tabaci whiteflies and CBSD. The general patterns of association between $B$. tabaci abundance, CBSD incidence and altitude are illustrated in Figures 7 and 8 . The general trend toward declining CBSD incidence with increasing altitude is

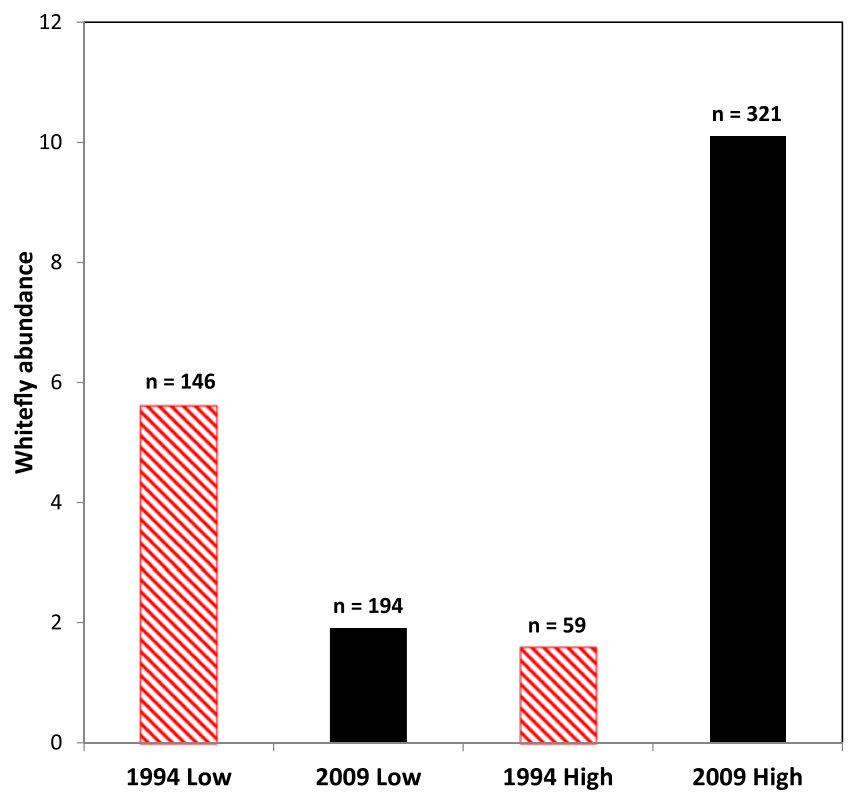

Fig. 3. Change in abundance of Bemisia tabaci whitefly adults in low $(<800$ masl) and high (>800 masl) altitude districts of Tanzania between 1994 and 2009. Whitefly abundance values are the mean number of B. tabaci adults on the top five leaves of a single sampled shoot per plant. 
apparent from both figures (although much stronger for the Coastal Zone), as is the similar trend for whiteflies in the Coastal Zone. For whiteflies in the Lake (CBSD) Zone, however, there is no clear-cut relation with either CBSD incidence or altitude. These observations are supported by the outcomes of regression analyses (Table 2), in which strong, positive, linear associations are confirmed for $B$. tabaci abundance and CBSD incidence in the Coastal Zone $(P<0.001)$ and all zones $(P<0.001)$, while the association in the Lake (CBSD) Zone alone is weakly significant $(P=0.004)$. Considered together, these results give strong support for the role of $B$. tabaci as vector of the viruses that cause CBSD, but suggest that the whitefly populations in the Coast and Lake Zones respond differently to environmental factors.
Relationship between environmental factors and CBSD. Regression analysis was used to examine the relationships between minimum temperature (in the coldest month of July), total annual rainfall, and length of growing period with incidence and severity of CBSD. There was considerable variation within environmental factors for both Zones (Table 3). In general, Coastal Zone sites were hotter than Lake (CBSD) Zone sites, while the greater range of annual rainfall in the Lake (CBSD) Zone meant that there was also a greater range of variation in growing periods than in the Coastal Zone. There were strongly positive linear relationships between CBSD incidence and temperature for all three zonal groupings (Table 4). By contrast, relationships between CBSD incidence and

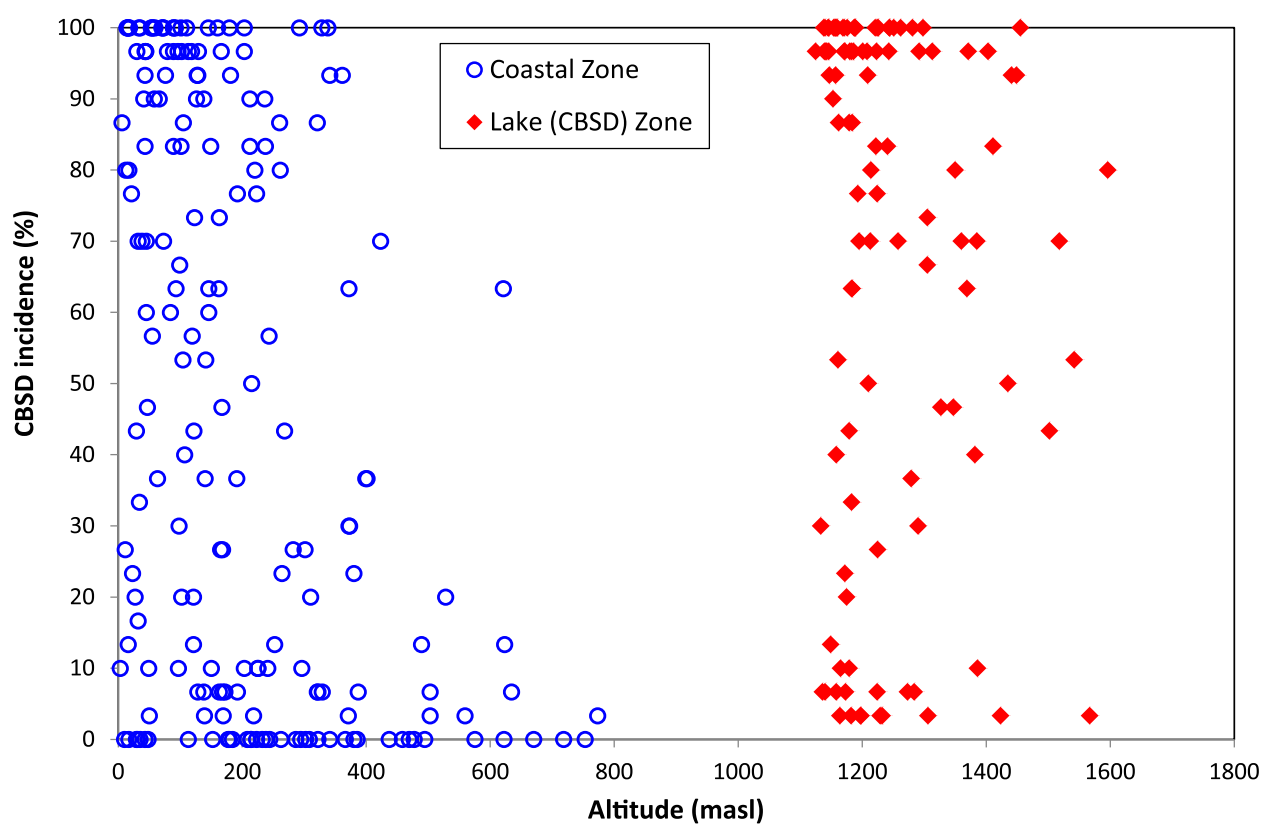

Fig. 4. Altitudinal variation in Cassava brown streak disease (CBSD) incidence for all 374 fields in the Coastal and Lake (CBSD) Zones of Tanzania, 2009.

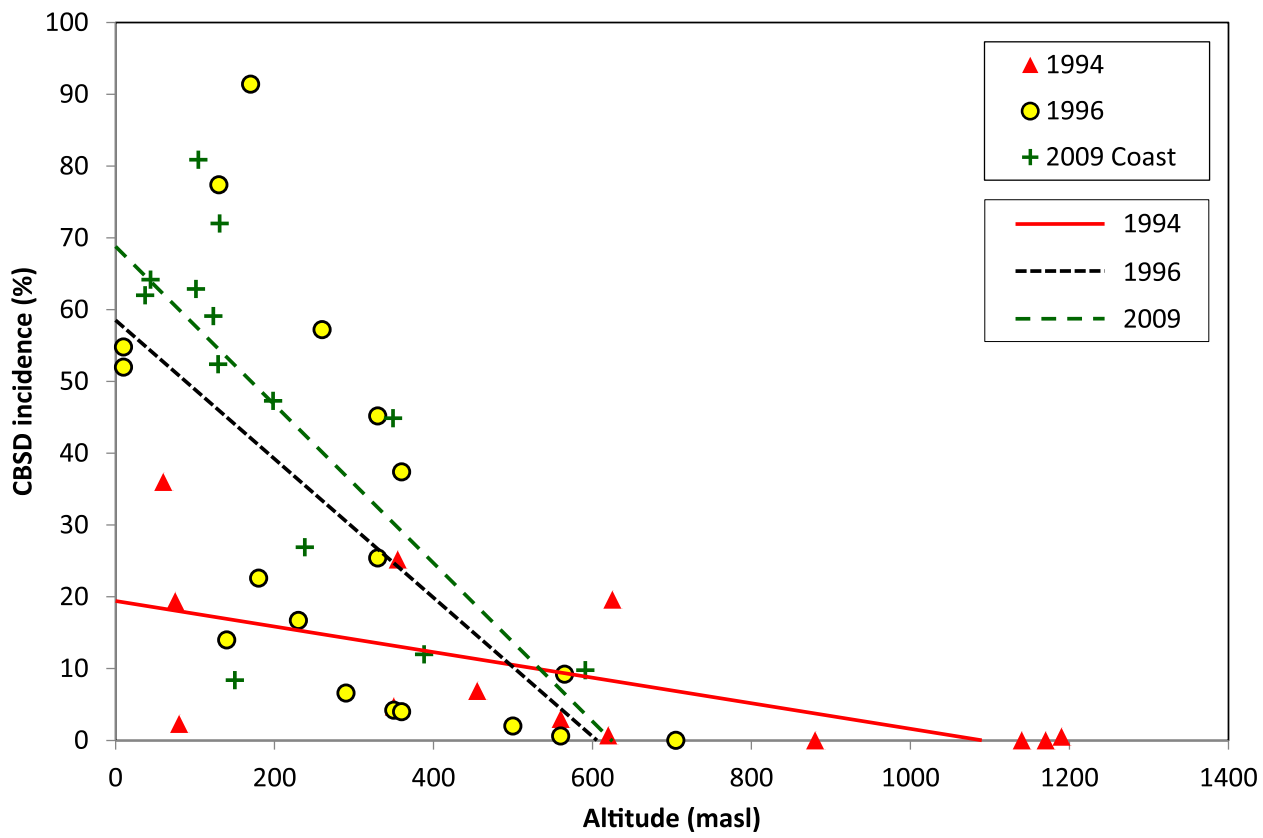

Fig. 5. Relationship between altitude and Cassava brown streak disease (CBSD) incidence in Tanzania in 1994 (Legg and Raya 1998), 1996 (Hillocks et al. 1998), and for the Coastal Zone of Tanzania in 2009 (this study). 1994: $y=19.5-0.018 x\left(r^{2}=0.38, F=6.84, P=0.024, n=13\right) ; 1996: y=58.2-0.096 x\left(r^{2}=0.42, F=\right.$ $11.59, P=0.0036, n=18)$; and 2009 Coast: $y=68.4-0.11 x\left(r^{2}=0.51, F=11.49, P=0.006, n=13\right)$. 
rainfall were not significant for any of the zones and growing period similarly showed no clear relationship with CBSD incidence.

None of the environmental variables appeared to have a strong effect on CBSD symptomatology, as determined through CBSD severity scoring, although the generally higher CBSD severity reported from the Coastal Zone was reflected in a strongly significant inverse relationship between CBSD severity and minimum temperature.

There was a strong relationship between CBSD incidence and CBSD severity for all zones, and this relationship was strongest for the Coastal Zone (Table 4).

Relationship between environmental factors and $B$. tabaci whiteflies. Whiteflies responded differently to each of the three environmental variables. In the Coastal Zone, rainfall was the strongest determinant of B. tabaci abundance, followed by temperature (Table 2). Whiteflies were favored by higher minimum temperatures but lower annual rainfall. By contrast, in the Lake (CBSD) Zone, the two most important factors affecting $B$. tabaci abundance were rainfall and growing period. In both cases whitefly numbers were positively related to the environmental factors. The greater significance of growing period in the Lake (CBSD) Zone can be explained by the much greater range of growing periods occurring there in comparison with the Coastal Zone, which was climatically more uniform. The fact that minimum temperature was not a significant factor determining whitefly abundance in the Lake (CBSD) Zone, where minimum temperatures were overall much lower than in the Coastal Zone, demonstrates the different temperature adaptation characteristics of $B$. tabaci occurring on cassava in the northwestern part of Tanzania.

\section{DISCUSSION}

Although CBSD has been known from some parts of East Africa for many decades, it is only since 2004 that it has been recognized as a major constraint to the region's cassava production and as a threat to the crop across a much larger part of tropical Africa. This renewed interest has arisen following an outbreak of the disease in the Great Lakes region of East and Central Africa-an area that had hitherto been considered to be outside the "natural" range of the viruses causing CBSD (Bock 1994; Nichols 1950). With this expanding research interest has come a desire to understand the reasons for the change in the status of this disease, and more specifically,

TABLE 2. Regression analyses of whitefly abundance versus other factors (Cassava brown streak disease [CBSD] incidence and environmental variables)

\begin{tabular}{|c|c|c|c|c|c|c|c|}
\hline Location & Factor & $N$ & Coefficient & Constant & $r^{2}$ & $F$ value & $P$ value \\
\hline All zones & $\begin{array}{l}\text { CBSD foliar incidence } \\
\text { Altitude } \\
\text { Min temp. } \\
\text { Annual rainfall } \\
\text { Growing period }\end{array}$ & $\begin{array}{l}374^{\mathrm{a}} \\
374 \\
374 \\
374 \\
374\end{array}$ & $\begin{array}{c}17.0 \\
0.00017 \\
-0.00026 \\
-0.000032 \\
0.0040\end{array}$ & $\begin{array}{r}36.5 \\
0.30 \\
0.85 \\
0.45 \\
-0.40\end{array}$ & $\begin{array}{l}0.039 \\
0.038 \\
0.014 \\
0.00009 \\
0.063\end{array}$ & $\begin{array}{l}14.9 \\
14.6 \\
5.4 \\
0.034 \\
25.0\end{array}$ & $\begin{array}{c}<0.001 \\
<0.001 \\
0.02 \\
0.85 \\
<0.001\end{array}$ \\
\hline Coastal Zone & $\begin{array}{l}\text { CBSD foliar incidence } \\
\text { Altitude } \\
\text { Min. temp. } \\
\text { Annual rainfall } \\
\text { Growing period }\end{array}$ & $\begin{array}{l}194 \\
194 \\
194 \\
194 \\
194\end{array}$ & $\begin{array}{l}32.1 \\
-0.00060 \\
0.043 \\
-0.00085 \\
0.00056\end{array}$ & $\begin{array}{r}36.8 \\
0.43 \\
-0.48 \\
1.29 \\
0.20\end{array}$ & $\begin{array}{l}0.064 \\
0.10 \\
0.056 \\
0.14 \\
0.0017\end{array}$ & $\begin{array}{r}13.0 \\
21.4 \\
11.3 \\
31.1 \\
0.3\end{array}$ & $\begin{array}{c}<0.001 \\
<0.001 \\
<0.001 \\
<0.001 \\
0.30\end{array}$ \\
\hline $\begin{array}{l}\text { Lake } \\
\text { (CBSD) Zone }\end{array}$ & $\begin{array}{l}\text { CBSD foliar incidence } \\
\text { Altitude } \\
\text { Min. temp. } \\
\text { Annual rainfall } \\
\text { Growing period }\end{array}$ & $\begin{array}{l}180^{\mathrm{a}} \\
180 \\
180 \\
180 \\
180\end{array}$ & $\begin{array}{l}15.8 \\
0.00023 \\
0.00034 \\
0.0017 \\
0.0048\end{array}$ & $\begin{array}{r}31.8 \\
0.25 \\
0.48 \\
-1.31 \\
-0.48\end{array}$ & $\begin{array}{l}0.047 \\
0.0017 \\
0.000019 \\
0.14 \\
0.087\end{array}$ & $\begin{array}{l}8.7 \\
0.30 \\
0.0034 \\
28.3 \\
16.9\end{array}$ & $\begin{array}{l}0.004 \\
0.59 \\
0.95 \\
<0.001 \\
<0.001\end{array}$ \\
\hline
\end{tabular}

a Only includes sampled districts that were part of the CBSD-affected region of the Lake Zone.

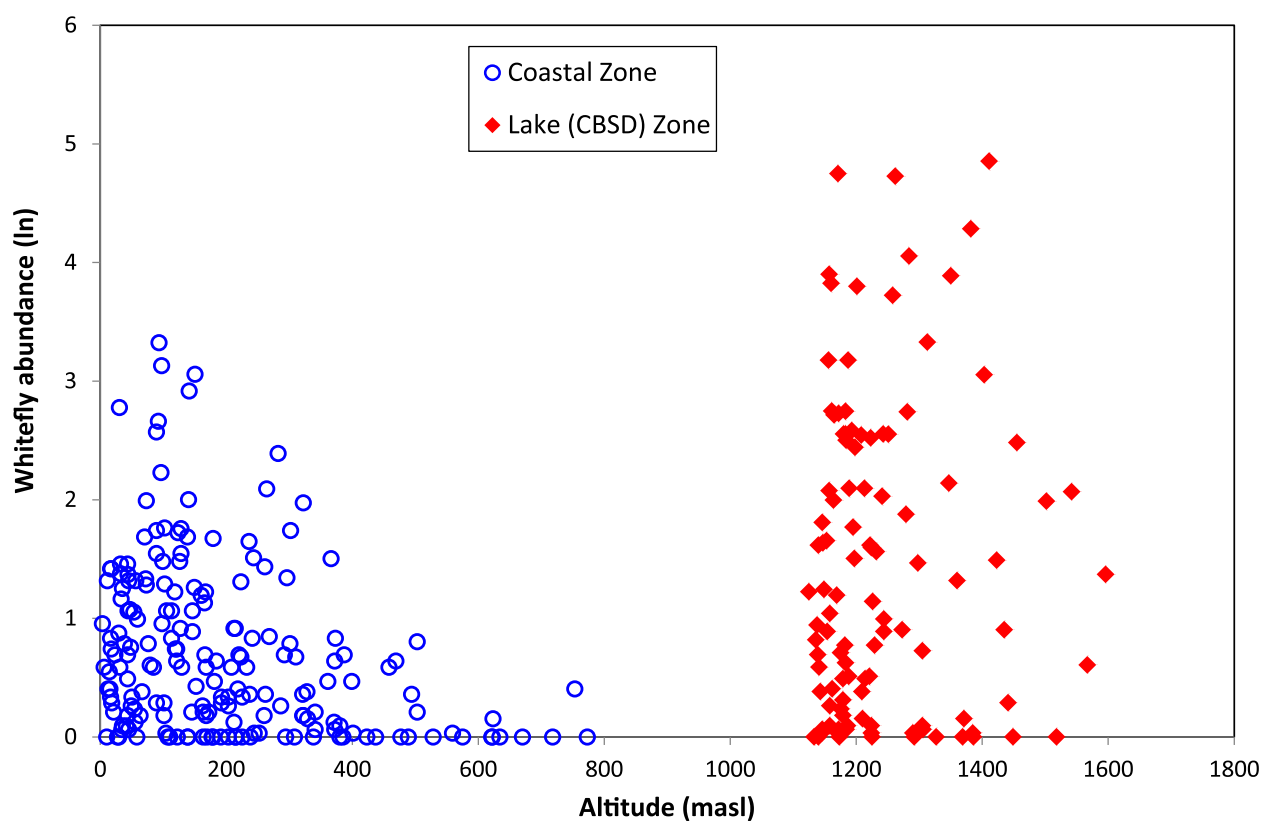

Fig. 6. Altitudinal variation in whitefly abundance for all 374 fields in the Coastal and Lake (cassava brown streak disease [CBSD]) Zones of Tanzania, 2009. Whitefly abundance values are the natural log transformed values $(\mathrm{ln}+1)$ for the mean number of Bemisia tabaci adults on the top five leaves of a single sampled shoot per plant. 
the biological and environmental factors linked to the increased apparent virulence of CBSVs.

The study presented here describes the most comprehensive country-level assessment of CBSD reported to date, involving 515 cassava plantings distributed through the two most important cassavagrowing regions of Tanzania. Overall incidence of CBSD was $31.7 \%$, although it was higher in the 194 fields of the eastern Coastal Zone (46.5\%) than in the 321 fields of the northwestern Lake Zone (22.6\%). The three districts with highest incidences, however, were all in the Lake Zone. The current higher incidence in the Coastal Zone is probably partly a consequence of the fact that the CBSD epidemic is still spreading in northwestern Tanzania, where the most westerly districts are as yet unaffected. Since 2004, CBSD has been spreading through the Great Lakes region of East and Central
Africa, affecting first Uganda, then Kenya, northwestern Tanzania, Burundi, and eastern DR Congo (Alicai et al. 2007; Bigirimana et al. 2011; Legg et al. 2011; Mulimbi et al. 2012). Some of the earliest affected areas of southern Uganda, western Kenya, and the eastern part of northwestern Tanzania can now be considered as endemic for CBSD, although for much of the rest of the Great Lakes region the situation can better be described as an "expanding epidemic." Although $B$. tabaci whiteflies are evidently playing a major role in the spread of this epidemic through their vectoring of CBSVs (Maruthi et al. 2005), it is certainly also true that movements of infected planting material are also an important contributory factor (Legg et al. 2011).

Comparison of the 2009 survey with earlier assessments conducted in 1993/94 reveals increases of CBSD incidence in both

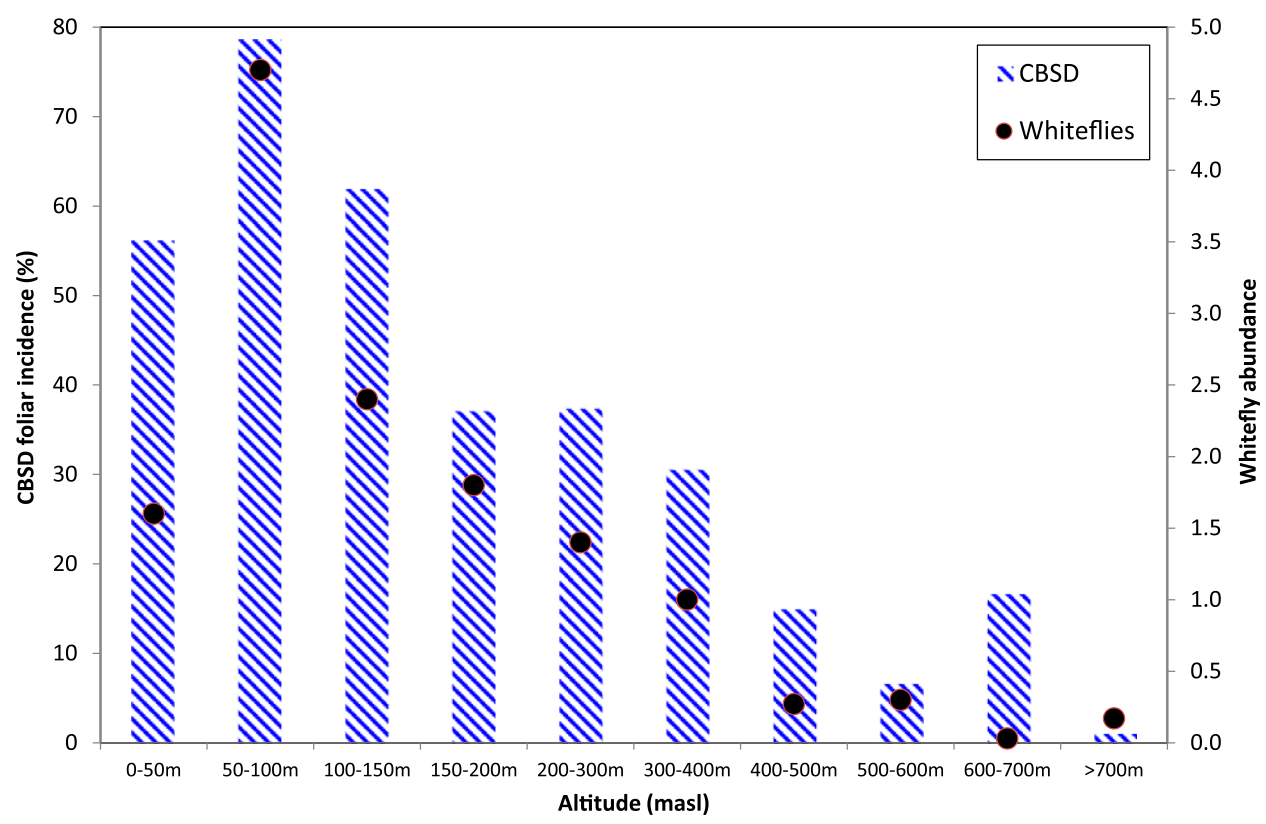

Fig. 7. Cassava brown streak disease (CBSD) incidence and Bemisia tabaci whitefly abundance, Coastal Zone of Tanzania, 2009. Whitefly abundance values are the mean number of $B$. tabaci adults on the top five leaves of a single sampled shoot per plant.

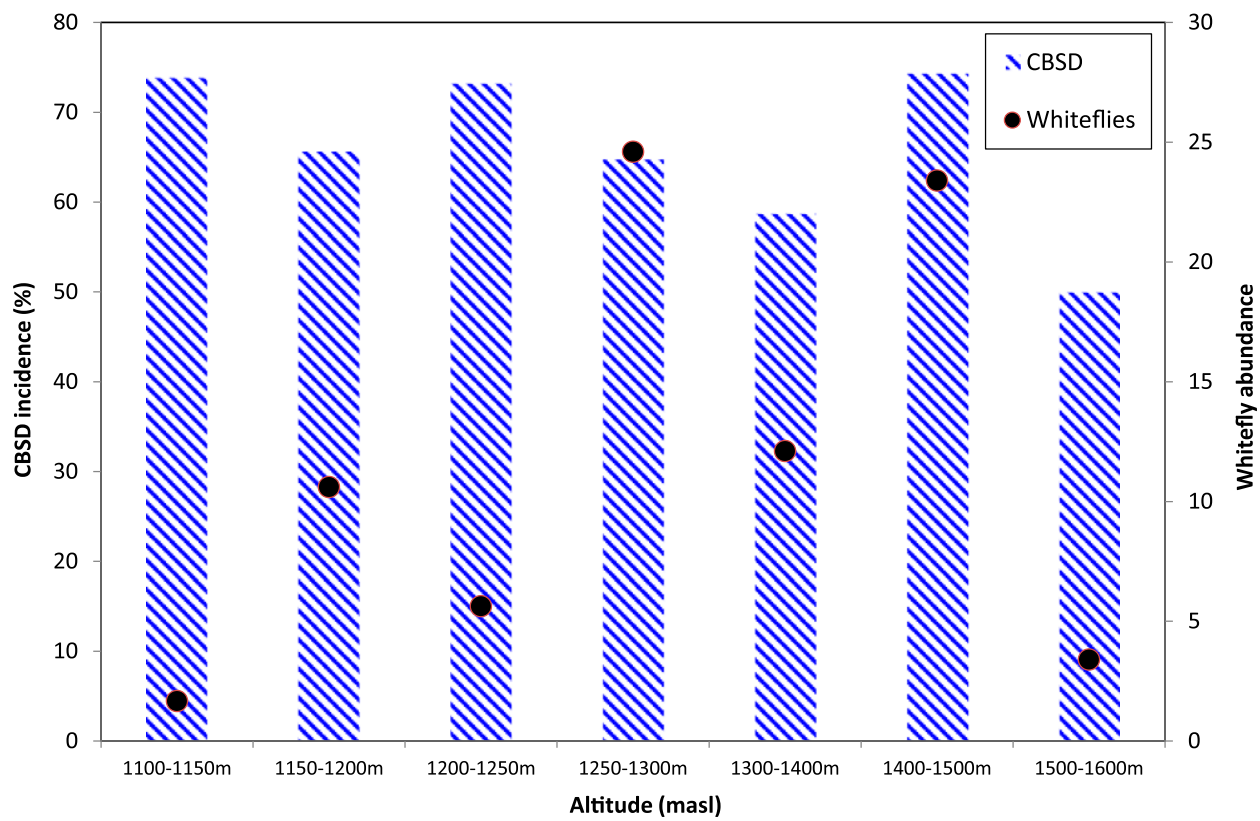

Fig. 8. Cassava brown streak disease (CBSD) incidence and Bemisia tabaci whitefly abundance, Lake (CBSD) Zone of Tanzania, 2009. Whitefly abundance values are the mean number of $B$. tabaci adults on the top five leaves of a single sampled shoot per plant. 
the Lake Zone (from $0.2 \%$ in $1993 / 94$ to $22.6 \%$ in 2009) and the endemic Coastal Zone (from $14.8 \%$ in $1993 / 94$ to $46.5 \%$ in 2009). Although the reasons for the increase in the Coastal Zone are unclear, it may be that there have been changes in incidence over time of the different virus species and strains causing CBSD. Although it is now known that CBSV and UCBSV occur together in the CBSD-affected regions of Kenya, Malawi, Uganda, and Tanzania (Mbanzibwa et al. 2011), there are currently no detailed virus incidence data from any region, and therefore no information to indicate whether changes in the relative prevalences and distributions of the two species are changing. This is an important topic for future study.

The greater severity of CBSD symptoms observed in the Coastal Zone, relative to the Lake Zone, might similarly be related to differences in relative distribution of species of CBSVs. However, evidence from experiments conducted under controlled conditions suggests that symptom differences may be a consequence of strain variation (Mohammed et al. 2012). These experiments also confirmed that the recent outbreak of CBSD in Uganda (and by association, also northwestern Tanzania) was not the consequence of the appearance and spread of a new supervirulent CBSV species or strain, since UCBSV strains occurring in Uganda were shown to be less severe than CBSV strains obtained from coastal regions of Tanzania and Mozambique (Mohammed et al. 2012).

The current study demonstrated the major change that has taken place in populations of the whitefly vector of CBSVs, between 1993/94 and 2009. While very few adults of B. tabaci were recorded from cassava in northwestern Tanzania in 1993/94, by 2009 populations in this region were significantly greater than those in the coastal region. There is no evidence for any sustained change in populations of $B$. tabaci in coastal East Africa. However, there is substantial evidence for massive increases in $B$. tabaci populations through large parts of the cassava-growing areas of the Great Lakes region (Colvin et al. 2004; Legg and Ogwal 1998; Legg et al. 2011; OtimNape et al. 1996), and it is these "superabundant" populations of B. tabaci that have been implicated in the spread of the twin cassava virus pandemics of severe cassava mosaic disease (CMD) and CBSD (Legg et al. 2011). Evidence seems to suggest that the outbreak of CBSD in the Lake Zone of Tanzania has been driven by a change in the size of populations of the whitefly vector, $B$. tabaci, as elsewhere in East and Central Africa. Although CBSD is propagated by planting infected cuttings, major epidemics can only be driven through the activity of elevated populations of the whitefly vector. Data obtained through the current study fully support these conclusions.

The negative relationship between CBSD and altitude was first noted during the early years of research into CBSD (Nichols 1950). It was postulated, but not proven, that this observation was a consequence of the absence or inefficiency in the vectoring activity of whiteflies at altitudes greater than 1,000 masl. Several quantitative studies have subsequently confirmed this inverse relationship between altitude and CBSD incidence (Hillocks et al. 1999, 2002; Legg and Raya 1998). Data from the current study revealed a 'two-step' relationship between CBSD and altitude. Considering the Coastal Zone alone, there was a strong inverse relationship between CBSD and altitude. However, a similar trend was also

TABLE 3. Ranges in environmental factors, Tanzania 2009

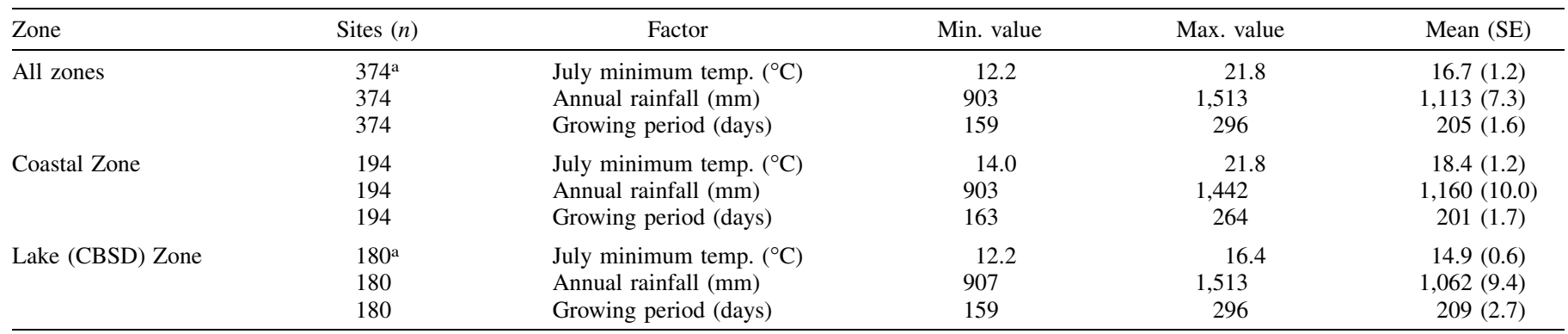

${ }^{a}$ Includes sampled districts that were part of the cassava brown streak disease-affected region of the Lake Zone.

TABLE 4. Regression analyses of environmental factors versus cassava brown streak disease (CBSD) foliar incidence and CBSD severity

\begin{tabular}{|c|c|c|c|c|c|c|c|c|}
\hline Location & Factor 1 & Factor 2 & $N$ & Coefficient & Constant & $r^{2}$ & $F$ value & $P$ value \\
\hline All zones & $\begin{array}{l}\text { CBSD foliar incidence } \\
\text { CBSD foliar incidence } \\
\text { CBSD foliar incidence } \\
\text { CBSD severity } \\
\text { CBSD severity } \\
\text { CBSD severity }\end{array}$ & $\begin{array}{l}\text { Min temp. } \\
\text { Annual rainfall } \\
\text { Growing period } \\
\text { Min temp. } \\
\text { Annual rainfall } \\
\text { Growing period }\end{array}$ & $\begin{array}{l}374^{\mathrm{a}} \\
374 \\
374 \\
263^{\mathrm{b}} \\
263 \\
263\end{array}$ & $\begin{array}{l}0.56 \\
0.0088 \\
-0.081 \\
0.0086 \\
0.00068 \\
-0.0033\end{array}$ & $\begin{array}{r}-49.6 \\
33.8 \\
27.1 \\
1.08 \\
1.80 \\
3.23\end{array}$ & $\begin{array}{l}0.089 \\
0.00089 \\
0.0034 \\
0.15 \\
0.036 \\
0.036\end{array}$ & $\begin{array}{c}36.1 \\
0.33 \\
1.30 \\
46.9 \\
9.8 \\
9.7\end{array}$ & $\begin{array}{r}<0.001 \\
0.57 \\
0.27 \\
<0.001 \\
0.002 \\
0.002\end{array}$ \\
\hline Coastal Zone & $\begin{array}{l}\text { CBSD foliar incidence } \\
\text { CBSD foliar incidence } \\
\text { CBSD foliar incidence } \\
\text { CBSD severity } \\
\text { CBSD severity } \\
\text { CBSD severity }\end{array}$ & $\begin{array}{l}\text { Min temp. } \\
\text { Annual rainfall } \\
\text { Growing period } \\
\text { Min temp. } \\
\text { Annual rainfall } \\
\text { Growing period }\end{array}$ & $\begin{array}{l}194 \\
194 \\
194 \\
155^{b} \\
155 \\
155\end{array}$ & $\begin{array}{l}1.02 \\
-0.0031 \\
0.41 \\
-0.00093 \\
0.00029 \\
-0.0023\end{array}$ & $\begin{array}{r}-140.8 \\
50.4 \\
-34.5 \\
2.92 \\
2.41 \\
3.21\end{array}$ & $\begin{array}{l}0.19 \\
0.00011 \\
0.054 \\
0.00090 \\
0.0069 \\
0.011\end{array}$ & $\begin{array}{c}45.8 \\
0.02 \\
11.0 \\
0.14 \\
1.06 \\
1.63\end{array}$ & $\begin{array}{c}<0.001 \\
0.88 \\
0.001 \\
0.71 \\
0.31 \\
0.20\end{array}$ \\
\hline $\begin{array}{l}\text { Lake } \\
\text { (CBSD) Zone }\end{array}$ & $\begin{array}{l}\text { CBSD foliar incidence } \\
\text { CBSD foliar incidence } \\
\text { CBSD foliar incidence } \\
\text { CBSD severity } \\
\text { CBSD severity } \\
\text { CBSD severity }\end{array}$ & $\begin{array}{l}\text { Min temp. } \\
\text { Annual rainfall } \\
\text { Growing period } \\
\text { Min temp. } \\
\text { Annual rainfall } \\
\text { Growing period }\end{array}$ & $\begin{array}{l}180^{\mathrm{a}} \\
180 \\
180 \\
108^{\mathrm{b}} \\
108 \\
108\end{array}$ & $\begin{array}{l}2.13 \\
0.0059 \\
-0.037 \\
0.0085 \\
-0.0002 \\
-0.0017\end{array}$ & $\begin{array}{r}-276.6 \\
33.9 \\
47.9 \\
1.00 \\
2.52 \\
2.63\end{array}$ & $\begin{array}{l}0.14 \\
0.00030 \\
0.00093 \\
0.051 \\
0.0069 \\
0.036\end{array}$ & $\begin{array}{l}29.8 \\
0.054 \\
0.17 \\
5.6 \\
0.73 \\
4.0\end{array}$ & $\begin{array}{l}<0.001 \\
0.82 \\
0.69 \\
0.019 \\
0.39 \\
0.049\end{array}$ \\
\hline $\begin{array}{l}\text { All zones } \\
\text { Coastal Zone } \\
\text { Lake (CBSD) Zone }\end{array}$ & $\begin{array}{l}\text { CBSD foliar incidence } \\
\text { CBSD foliar incidence } \\
\text { CBSD foliar incidence }\end{array}$ & $\begin{array}{l}\text { CBSD severity } \\
\text { CBSD severity } \\
\text { CBSD severity }\end{array}$ & $\begin{array}{l}263^{\mathrm{b}} \\
155^{\mathrm{b}} \\
108^{\mathrm{b}}\end{array}$ & $\begin{array}{l}0.0036 \\
0.0059 \\
0.0020\end{array}$ & $\begin{array}{l}2.34 \\
2.41 \\
2.13\end{array}$ & $\begin{array}{l}0.070 \\
0.18 \\
0.070\end{array}$ & $\begin{array}{r}20.0 \\
34.5 \\
7.5\end{array}$ & $\begin{array}{r}<0.001 \\
<0.001 \\
0.007\end{array}$ \\
\hline
\end{tabular}

a Only includes sampled districts that were part of the CBSD-affected region of the Lake Zone.

b Only includes fields in which CBSD-affected plants were present among those that were sampled. 
demonstrated for the Lake Zone. In the Coastal Zone, highest CBSD incidences occur at sites nearest to sea level, while in the Lake Zone, similarly high incidences occur at altitudes between 1,100 and 1,200 masl, although here the effect of altitude is much less significant. This suggests that the coastal and inland CBSD/whitefly/ cassava pathosystems respond differently to the environmental factors that influence them. Evidence points increasingly to the whitefly, B. tabaci, as the component of the system that has changed, becoming better adapted to cassava and to the environmental conditions prevalent in the mid-altitude ( 800 to 1,500 masl) cassava-growing zones of the Great Lakes region. Regressions of B. tabaci abundance data with the three environmental variables (minimum temperature during the coolest month of July, annual rainfall, and length of growing period) suggested differences in the responses of $B$. tabaci populations from the Coastal and Lake Zones. Coastal B. tabaci were most strongly influenced by rainfall (inversely) and minimum temperature, while $B$. tabaci in the Lake Zone were most strongly affected by rainfall (directly) and growing period. These data indicate that while coastal $B$. tabaci are negatively affected by low minimum temperatures, the same is not the case for B. tabaci in the Lake Zone, although maximum altitudes and therefore minimum temperatures are effectively constrained as little cassava is grown at altitudes greater than approximately 1,800 masl. Research elsewhere has provided evidence for distinct characteristics of "superabundant" B. tabaci associated with cassava virus pandemics in the Great Lakes region of East and Central Africa, both in terms of their genetics (Legg et al. 2002, 2014b; Mugerwa et al. 2012), as well as their fitness on cassava (Mugerwa et al. 2013) and ability to colonize hosts other than cassava (Sseruwagi et al. 2006). Results presented here suggest that further study on the temperature adaptation of $B$. tabaci populations from different parts of Tanzania and the wider region is merited.

Minimum temperature was by far the most important environmental determinant of CBSD incidence for all zone groupings considered in this study, and regression analyses provide a means of quantifying these relationships and making predictive assessments. The geographic coverage of the current study was too narrow to allow for the development of broadly-applicable predictions of geographic areas that are likely to be suitable or unsuitable for the establishment and spread of CBSD. This should, however, be a goal of future surveillance work on CBSD. In view of the current interest in this emerging disease of cassava, and the fear of wider spread (Legg et al. 2014a), there are likely to be future opportunities to obtain the types of multi-country surveillance data that would facilitate such analyses. Predictive tools could be of great value in view of the current threat posed by cassava virus pandemics to parts of central, southern and West Africa, but beyond that, to make ex ante forecasts of likely impacts in the Asian and Latin American tropics where cassava is an important crop. A global niche modeling approach has been used previously to predict relative suitabilities for a range of cassava pests and diseases, including CBSD (Campo et al. 2011). At a smaller geographic scale, more than 30 environmental variables and GIS-based kriging techniques were also used to develop predictive models for cassava mosaic disease in Rwanda and Burundi (Bouwmeester et al. 2012). The future challenge will be to combine these analytical methodologies with improved and more geographically representative data sets, coupled with an improved fundamental understanding of the key environmental variables that affect systems such as the $B$. tabaci/CBSD/cassava pathosystem. With respect specifically to $B$. tabaci whiteflies, this will require greatly improved knowledge of (i) the genetic and biological diversity within cassava-colonizing populations of $B$. tabaci and their effects on transmission of CBSVs (ii) the specific responses of different $B$. tabaci populations to environmental factors such as temperature and humidity (iii) the contrasting capabilities of different B. tabaci populations to feed on and colonize crop and weed hosts other than cassava, and (iv) the effect of topographical factors on long-distance dispersal of B. tabaci.
Significantly, whitefly populations that are responsible for transmitting CBSVs appear to be most favored by the highest temperature conditions found in the parts of East and Central Africa where cassava is a key crop. The anticipated global warming that will result from projected future increases in $\mathrm{CO}_{2}$ emissions therefore looks set to further exacerbate the whitefly-driven cassava virus pandemics and increase the likelihood of their occurrence elsewhere in Africa and the tropics. This highlights the increasing urgency of efforts to develop effective and sustainable approaches for the management of Bemisia whiteflies and the viruses that they transmit. These themes look certain to provide some of the most important research and development objectives for cassava researchers in the coming decades.

\section{ACKNOWLEDGMENTS}

We thank the Great Lakes Cassava Initiative (GLCI) project through IITA for funding the survey work, and the Government of Tanzania, through the Ministry of Agriculture and Cooperatives for permission to conduct the research and for allowing national staff to participate. Special thanks go to Mr. Liwa (Kibaha Sugarcane Research Institute), C. Busungu (IITA), Mr. Chirimi (Ukiriguru Research Institute), C. Bagambisa and A. Mohamed (Kizimbani Research Institute-Zanzibar), A. Njapuka (Naliendele Research Institute), and P. Rweyemamu (Tumbi Research Station) for their participation in the collection and processing of survey data; and $\mathrm{M}$. Thresh for commenting on the manuscript.

\section{LITERATURE CITED}

Alicai, T., Omongo, C. A., Maruthi, M. N., Hillocks, R. J., Baguma, Y., Kawuki, R., Bua, A., Otim-Nape, G. W., and Colvin, J. 2007. Re-emergence of cassava brown streak disease in Uganda. Plant Dis. 91:24-29.

Anonymous. 2008. Cassava brown streak virus disease: Farmers' perspectives on a new outbreak of this disease from the Lake zone of Tanzania. http:// www.youtube.com/watch? $\mathrm{v}=\mathrm{nCJdws} 9 \mathrm{CnUw}$

Bigirimana, S., Barumbanze, P., Ndayihanzamaso, P., Shirima, R., and Legg, J. P. 2011. First report of cassava brown streak disease and associated Ugandan cassava brown streak virus in Burundi. Plant Pathol. 53:231.

Bock, K. R. 1994. Studies on cassava brown streak disease in Kenya. Trop. Sci. 34:134-145.

Bouwmeester, H., Heuvelink, G. B. M., Legg, J. P., and Stoorvogel, J. J. 2012. Comparison of disease patterns assessed by three independent surveys of cassava mosaic disease in Rwanda and Burundi. Plant Pathol. 61:399-412.

Campo, B. V. H., Hyman, G., and Bellotti, A. 2011. Threats to cassava production: Known and potential geographic distribution of four key biotic constraints. Food Sec. 3:329-345.

Colvin, J., Omongo, C. A., Maruthi, M. N., Otim-Nape, G. W., and Thresh, J. M. 2004. Dual begomovirus infections and high Bemisia tabaci populations drive the spread of a cassava mosaic disease pandemic. Plant Pathol. 53:577-584.

Environmental Research Group Oxford. 2005. Agro-ecological distributions for Africa-Length of growing period. http://www.ergoonline.co.uk

Hijmans, R. J., Cameron, S. E., Parra, J. L., Jones, P. J., and Jarvis, A. 2005. Very high resolution interpolated climate surfaces for global land areas. Int. J. Climatol. 25:1965-1978.

Hillocks, R. J., and Jennings, D. L. 2003. Cassava brown streak disease: A review of present knowledge and research needs. Int. J. Pest Manage. 49:225-234.

Hillocks, R. J., Raya, M., and Thresh, J. M. 1996. The association between root necrosis and above-ground symptoms of brown streak virus infection of cassava in Southern Tanzania. Int. J. Pest Manage. 42:285-289.

Hillocks, R. J., Raya, M. D., and Thresh, J. M. 1999. Distribution and symptom expression of cassava brown streak disease in southern Tanzania. Afr. J. Root Tuber Crops 3:57-61.

Hillocks, R. J., Thresh, J. M., Tomas, J., Botao, M., Macia, R., and Zavier, R. 2002. Cassava brown streak disease in northern Mozambique. Int. J. Pest Manage. 48:178-181.

Jameson, J. D. 1964. Cassava mosaic disease in Uganda. E. Afr. Agric. J. 29: 208-213.

Jeremiah, S. 2014. The role of the whitefly (Bemisia tabaci (Gennadius)) in the spread and transmission of cassava brown streak and cassava mosaic viruses in field and semi-field conditions. Ph.D. thesis. University of Dar es Salaam, Dar es Salaam, Tanzania.

Legg, J. P., French, R., Rogan, D., Okao-Okuja, G., and Brown, J. K. 2002. A distinct Bemisia tabaci (Gennadius) (Hemiptera: Sternorrhyncha: Aleyrodidae) genotype cluster is associated with the epidemic of severe cassava mosaic virus disease in Uganda. Mol. Ecol. 11:1219-1229. 
Legg, J. P., Jeremiah, S. C., Obiero, H. M., Maruthi, M. N., Ndyetabula, I., Okao-Okuja, G., Bouwmeester, H., Bigirimana, S., Tata-Hangy, W., Gashaka, G., Mkamilo, G., Alicai, T., and Lava Kumar, P. 2011. Comparing the regional epidemiology of the cassava mosaic and cassava brown streak pandemics in Africa. Virus Res. 159:161-170.

Legg, J. P., and Ogwal, S. 1998. Changes in the incidence of African cassava mosaic geminivirus and the abundance of its whitefly vector along southnorth transects in Uganda. J. Appl. Entomol. 122:169-178.

Legg, J. P., and Raya, M. 1998. A survey of cassava virus diseases in Tanzania. Int. J. Pest Manage. 44:17-23.

Legg, J. P., Somado, E. A., Barker, I., Beach, L., Ceballos, H., Cuellar, W., Elkhoury, W., Gerling, D., Helsen, J., Hershey, C., Jarvis, A., Kulakow, P., Kumar, L., Lorenzen, J., Lynam, J., McMahon, M., Maruthi, G., Miano, D., Mtunda, K., Ntawuruhunga, P., Okogbenin, E., Pezo, P., Terry, E., Thiele, G., Thresh, M., Wadsworth, J., Walsh, S., Winter, S., Tohme, J., and Fauquet, C. 2014a. A global alliance declaring war on cassava viruses in Africa. Food Secur. 6:231-248.

Legg, J. P., Sseruwagi, P., Boniface, S., Okao-Okuja, G., Shirima, R., Bigirimana, S., Gashaka, G., Herrmann, H.-W., Jeremiah, S. C., Obiero, H. M., Ndyetabula, I., Tata-Hangy, W., Masembe, C., and Brown, J. K. 2014b. Spatio-temporal patterns of genetic change amongst populations of cassava Bemisia tabaci whiteflies driving virus pandemics in East and Central Africa. Virus Res.

Manyong, V. M., Maeda, C., Kanju, E., and Legg, J. P. 2012. Economic damage of cassava brown streak disease in sub-Saharan Africa. Pages 61-68 in: Tropical Root and Tuber Crops and the Challenges of Globalization and Climate Change. R. U. Okechukwu and P. Ntawuruhunga, eds.11th ISTRCAB Symposium, Kinshasa, Democratic Republic of Congo.

Maruthi, M. N., Hillocks, R. J., Mtunda, K., Raya, M. D., Muhanna, M., Kiozia, H., Rekha, A. R., Colvin, J., and Thresh, J. M. 2005. Transmission of Cassava brown streak virus by Bemisia tabaci (Gennadius). J. Phytopathol. 153:307-312.

Mbanzibwa, D. R., Tian, Y. P., Tugume, A. K., Mukasa, S. B., Tairo, F., Kyamanywa, S., Kullaya, A., and Valkonen, J. P. T. 2009. Genetically distinct strains of cassava brown streak virus in the Lake Victoria basin and the Indian Ocean coastal area of East Africa. Arch. Virol. 154:353-359.

Mbanzibwa, D. R., Tian, Y. P., Tugume, A. K., Mukasa, S. B., Tairo, F., Kyamanywa, S., Kullaya, A., and Valkonen, J. P. T. 2010. Simultaneous virus-specific detection of the two cassava brown streak-associated viruses by RT-PCR reveals wide distribution in East Africa, mixed infections and infections in Manihot glaziovii. J. Virol. Methods 171:394-400.

Mbanzibwa, D. R., Tian, Y. P., Tugume, A. K., Patil, B. L., Yadav, J. S., Bagewadi, B., Abarshi, M. M., Alicai, T., Changadeya, W., Mkumbira, J.,
Muli, M. B., Mukasa, S. B., Tairo, F., Baguma, Y., Kyamanywa, S., Kullaya, A., Maruthi, M. N., Fauquet, C. M., and Valkonen, J. P. T. 2011. Evolution of cassava brown streak disease-associated viruses. J. Gen. Virol. 92:974-987.

Mohammed, I. U., Abarshi, M. M., Muli, B., Hillocks, R. J., and Maruthi, M. N. 2012. The symptoms and genetic diversity of cassava brown streak viruses infecting cassava in East Africa. Adv. Virol.

Monger, W. A., Seal, S., Isaac, A. M., and Foster, G. D. 2001. Molecular characterization of cassava brown streak virus coat protein. Plant Pathol. 50:527-534.

Mugerwa, H., Rey, M. E. C., Alicai, T., Ateka, E., Atuncha, H., Ndunguru, J., and Sseruwagi, P. 2012. Genetic diversity and geographic distribution of Bemisia tabaci (Gennadius) (Hemiptera: Aleyrodidae) genotypes associated with cassava in East Africa. Ecol. Evol. 2:2749-2762.

Mugerwa, H., Rey, M. E. C., Tairo, F., Ndunguru, J., and Sseruwagi, P. 2013. Two genotypes of sub-Saharan Africa 1 Bemisia tabaci (Gennadius) (Hemiptera: Aleyrodidae) associated with cassava in East Africa exhibit distinct biological differences in fecundity and development. Page 147 in: Book of abstracts. 12th International Symposium on Plant Virus Epidemiology, Arusha, Tanzania. http://www.iita.org/c/document_library/get_file? uuid=5ae26d0c-eb3f-4f6a-9a87-2db4ee0daed3\&groupId=839741

Mulimbi, W., Phemba, X., Assumani, B., Kasereka, P., Muyisa, S., Ugentho, H., Reeder, R., Legg, J. P., Laurenson, L., Weekes, R., and Thom, F. E. F. 2012. First report of Ugandan cassava brown streak virus on cassava in Democratic Republic of Congo. N. Dis. Rep. 26:11.

Nichols, R. F. J. 1950. The brown streak disease of cassava: Distribution, climatic effects and diagnostic symptoms. E. Afr. Agric. J. 15:154-160.

Otim-Nape, G. W., Thresh, J. M., and Fargette, D. 1996. Bemisia tabaci and cassava mosaic virus disease in Africa. Pages 319-350 in: Bemisia 1995: Taxonomy, Biology, Damage, Control and Management. D. Gerling and R. T. Meyer, eds. Intercept, Andover, UK.

Sseruwagi, P., Maruthi, M. N., Colvin, J., Rey, M. E. C., Brown, J. K., and Legg, J. P. 2006. Colonisation of non-cassava plant species by cassava whiteflies (Bemisia tabaci) (Gennadius) (Hemiptera: Aleyrodidae) in Uganda. Entomol. Exp. Appl. 119:145-153.

Storey, H. H. 1936. Virus diseases on East African plants. VI. A progress report on the studies of the diseases of cassava. E. Afr. Agric. J. 2:34-39.

Thresh, J. M., Fargette, D., and Otim-Nape, G. W. 1994. The viruses and virus diseases of cassava in Africa. Afr. Crop Sci. J. 2:459-478.

Winter, S., Koerbler, M., Stein, B., Pietruszka, A., Paape, M., and Butgereitt, A. 2010. The analysis of cassava brown streak viruses reveals the presence of a distinct virus species causing cassava brown streak disease in East Africa. J. Gen. Virol. 91:1365-1372. 